\title{
PENDUGAAN UMUR SIMPAN KERUPUK IKAN LELE DUMBO (Clarias gariepinus) PANGGANG DALAM KEMASAN PLASTIK METALIK DAN POLIPROPILEN
}

\section{Shelf Life Determination of Roasted Catfish Crackers Stored with Metallic and Polypropylene Packaging}

\author{
Diah Ikasari ${ }^{*}$, Theresia Dwi Suryaningrum 1 , Inti Mulyo Arti $^{2}$, dan Supriyadi ${ }^{3}$ \\ ${ }^{1}$ Balai Besar Riset Pengolahan Produk dan Bioteknologi Kelautan dan Perikanan, \\ JI. KS. Tubun Petamburan VI, Slipi, Jakarta, Indonesia \\ 2 Program Studi Teknik Industri, Fakultas Teknologi Industri, Universitas Gunadarma, \\ Jalan Margonda Raya No. 100, Beji, Jawa Barat \\ 3)Departemen Teknologi Produk Pangan dan Pertanian, Universitas Gadjah Mada, Yogyakarta \\ * Korespondensi Penulis: diah_ika263@yahoo.com
}

Diterima: 15 Februari 2017; Disetujui: 30 Mei 2017

\begin{abstract}
ABSTRAK
Tujuan dari penelitian ini adalah menentukan umur simpan kerupuk ikan lele dumbo panggang menggunakan pendekatan model kadar air kritis dengan 2 jenis kemasan yakni plastik metalik dan polipropilen. Kerupuk ikan ditentukan kadar air awal, kadar air kritis, kadar air kesetimbangan beserta nilai aktifitas air untuk dapat dimasukkan dalam persamaan Labuza. Permeabilitas, ketebalan, dan luas kemasan juga dianalisis sebagai variabel pendukung yang digunakan dalam persamaan Labuza. Titik kritis ditentukan berdasarkan hasil uji skor yang dilakukan oleh 21 panelis terlatih terhadap nilai kerenyahan produk kerupuk hingga produk dinyatakan tidak renyah (skor 2). Hasil perhitungan pendugaan umur simpan berdasarkan persamaan Labuza menunjukkan bahwa kerupuk ikan lele dumbo panggang dengan kemasan plastik metalik memiliki umur simpan yang lebih lama (329 hari) dibandingkan dengan plastik polipropilen (231 hari).
\end{abstract}

KATA KUNCI : lele dumbo, kerupuk ikan panggang, umur simpan, kadar air kritis, kemasan plastik

\begin{abstract}
Study aimed to determine the shelf life of roasted catfish crackers using critical moisture content model packed with two plastic packaging, namely metalized plastic and polypropilen plastic. The crackers were determined for their initial moisture content, critical moisture content, equilibrium moisture content, and water activity to be included in the Labuza equation. Permeability, thickness, and area of packaging were also analyzed as additional variable needed by Labuza equation. The critical point was determined based on the scoring test result conducted by 21 welltrained panelists for the crispness value of roasted catfish crackers until the crackers were scored not crispy. Result of the shelf life calculation using Labuza equation showed that the shelf life of roasted catfish crackers packed with metalized plastic was longer (329 days) compared to the one that packed with polypropilen plastic (231 days).
\end{abstract}

KEYWORDS: catfish, roasted fish crackers, shelf life, critical moisture content, plastic packaging

\section{PENDAHULUAN}

Kerupuk ikan merupakan makanan ringan yang sangat populer di Indonesia. Produk pangan ini terbuat dari karbohidrat tepung seperti sagu, tapioka, jagung, beras yang dibuat adonan dan mengalami proses gelatinisasi, dipotong tipis, dikeringkan dan dipanaskan pada suhu tinggi (Koswara, 2009). Pada proses pengolahan kerupuk, seringkali ditambahkan bahan lain seperti udang, ikan, dan lain-lain untuk meningkatkan citarasa dan kandungan protein pada kerupuk. Ikan lele dumbo (Clarias gariepinus) merupakan salah satu ikan air tawar yang dapat ditambahkan pada kerupuk karena mudah diperoleh, relatif murah, berukuran besar, serta mengandung kadar protein yang cukup tinggi yakni 16,80 $\pm 0,44 \%$ bb (Rossa, Narcisa, \& Maria, 2007) hingga 19,27 \pm $0,57 \%$ bb (Obande, Omeji, \& Ityumbe, 2012). Ikan lele dumbo diketahui mengandung asam amino tertinggi lisin $(1,49 \pm 0,12 \%$ bb) dan asam glutamat 
$(2,22 \pm 0,22 \%$ bb) (Rossa et al., 2007) sehingga dapat memberikan citarasa gurih pada kerupuk (Suryaningrum, Rosmawaty, ljah, Diah, \& Syamdidi 2014). Dengan meningkatnya kesadaran masyarakat akan pentingnya kesehatan, saat ini telah dikembangkan produk kerupuk ikan lele dumbo panggang dengan tujuan meminimalisir penggunaan minyak goreng yang dapat berdampak pada gangguan kesehatan.

Informasi mengenai umur simpan atau masa kadaluarsa suatu produk pangan mutlak diperlukan pada produk yang diperdagangkan karena pada dasarnya semua produk mengalami penurunan kualitas. Hal itu diamanatkan oleh UU No 18 tahun 2012 tentang Pangan dan UU Perlindungan Konsumen No.8 tahun 1999. Dengan demikian, informasi umur simpan kerupuk lele dumbo tanpa goreng juga diperlukan. Kerupuk ikan termasuk dalam makanan kering yang mudah mengalami kerusakan akibat penyerapan uap air dari lingkungan. Penentuan umur simpan untuk produk kerupuk ikan lele dumbo panggang yang relatif mudah rusak akibat penyerapan air dari lingkungan atau "melempem" sangat tepat apabila didekati dengan metode akselerasi model kadar air kritis dengan menggunakan persamaan Labuza (Herawati, 2008). Informasi penting yang diperlukan dalam persamaan tersebut adalah pola penyerapan uap (water vapor sorption isotherm/ isotermis sorpsi lembab/ISL). Isotermis sorpsi air adalah pola/kurva yang mengkorelasikan data kadar air dengan aktivitas air suatu bahan pada suhu yang sama (Adawiyah \& Soekarto, 2010).

Menurut Vazquez, Chenlo dan Moreira (2003) terdapat beberapa model untuk menggambarkan pola ISL antara lain Oswin (1946), Halsey (1948), Henderson (1952), Chen \& Clayton (1971), Caurie (1981), dan Guggenheim, Anderson \& De Boer (GAB) (1981). Caurie mendapatkan model yang berlaku untuk kebanyakan bahan pangan pada nilai $a_{w} 0,0-0,85$, sedangkan Halsey (1948) mengembangkan persamaan yang dapat digunakan untuk bahan makanan dengan nilai $a_{w} 0,1-0,81$. Persamaan Oswin (1946) berlaku untuk bahan pangan pada $a_{w}, 0,0-0,85$ dan cocok untuk kurva sorpsi isotermis yang berbentuk sigmoid. Model matematika Chen \& Clayton (1971) dan Hendersen (1952) berlaku untuk semua bahan pangan pada semua nilai $a_{w}$, dan Henderson (1952) lebih tepat untuk bahan pangan kering terutama biji-bijian. Untuk mengetahui model mana yang paling tepat digunakan untuk produk kerupuk lele dumbo panggang maka persamaan-persamaan tersebut diuji ketepatannya dengan menghitung nilai MRD (Mean Relative Determination). Jika nilai MRD $<5$ maka model sorpsi isotermis dapat menggambarkan keadaan yang sebenarnya atau sangat tepat. Model sorpsi isotermis dengan $5<$ MRD $<10$ menunjukkan bahwa model tersebut agak tepat menggambarkan keadaan sebenarnya dan jika MRD > 10 maka model tersebut tidak tepat menggambarkan kondisi sebenarnya. Model kurva sorpsi isotermis memiliki ketepatan model yang baik jika nilai MRD < 10\% (McMinn \& Magee, 1999; Sugiyono, Edi, Elvira, \& Hery, 2011; Tarigan, Prateepchaikul, Yamsaengsung, Sirichote, \& Tekasakul, 2006).

Penurunan kualitas dapat dihambat dengan metode pengemasan. Penggunaan bahan kemasan sangat menentukan umur simpan suatu produk. Selain itu, kemasan untuk bahan pangan harus aman dan memenuhi standar persyaratan kesehatan yang ditentukan. Dalam Undang - Undang No 7 Tahun 1996 pasal 16 ayat (1) tentang Pangan disebutkan bahwa "setiap orang yang memproduksi pangan untuk diedarkan dilarang menggunakan bahan apapun sebagai kemasan pangan yang dinyatakan terlarang dan atau yang dapat melepaskan cemaran yang merugikan atau membahayakan kesehatan manusia"

Bahan pengemas yang relatif murah, mudah diperoleh dan dibentuk adalah plastik. Salah satu jenis kemasan plastik yang banyak digunakan dalam industri pangan adalah polielefin, termasuk golongan ini polietilen (PE), polipropilen (PP) serta kopolimer lain. Kemasan plastik propilen dan metalik (Co-PP/ Me) menurut Peraturan KBPOM RI No.HK.00.05.55.6497 tentang Bahan Kemasan Pangan merupakan bahan dasar yang diijinkan untuk kemasan pangan. Plastik polipropilen (PP) memiliki kemampuan penghambat uap air yang cukup baik $\left(0,25 \mathrm{~g} / 100 \mathrm{~cm}^{2}, 24 \mathrm{jam}, 37,8 \stackrel{\circ}{\circ} \mathrm{C}, \mathrm{RH} 90 \%\right.$ ) (Allahvaisi, 2012; Anon, 2008) sedangkan plastik metalik dengan pelapisan metal pada plastik dapat meningkatkan sifat permeabilitas kemasan, sehingga diharapkan penggunaan plastik PP dan metalik sebagai pengemas dapat memperpanjang umur simpan kerupuk ikan lele dumbo panggang. Penelitian yang dilakukan oleh Septianingrum (2008) menunjukkan bahwa umur simpan tepung gaplek yang dikemas dengan plastik polipropilen dengan ketebalan $0,02 \mathrm{~mm} ; 0,03 \mathrm{~mm}$; $0,04 \mathrm{~mm} ; 0,05 \mathrm{~mm}$; dan $0,08 \mathrm{~mm}$ yang disimpan pada suhu $28{ }^{\circ} \mathrm{C} \mathrm{RH} 78 \%$ berturut-turut adalah 130 hari; 157 hari; 182 hari; 207 hari dan 264 hari. Hasil penelitian lain terhadap umur simpan keripik salak yang ditiriskan menggunakan spinner selama 30 detik dan disimpan menggunakan plastik metalik pada suhu $25^{\circ} \mathrm{C}$ adalah 95,06 hari (Sanjaya, 2007). Informasi mengenai umur simpan kerupuk ikan lele dumbo panggang belum banyak tersedia. Penelitian ini dilakukan untuk menentukan umur simpan kerupuk ikan lele dumbo panggang yang dikemas dengan menggunakan dua jenis pengemas yang berbeda melalui pendekatan penyerapan uap air produk. Dalam penelitian dievaluasi pula metoda pendekatan ISL yang paling tepat untuk menggambarkan pola ISL kerupuk lele dumbo panggang. 


\section{BAHAN DAN METODE}

\section{Bahan}

Bahan yang digunakan dalam penelitian ini adalah ikan lele dumbo yang diperoleh dari Parung, Bogor dengan berat rata-rata $0,89 \pm 0,21 \mathrm{~kg}$ per ekor. Bahan lain yang digunakan antara lain tepung tapioka, garam, gula, rumput laut matang yang telah dihaluskan, minyak sayur, MSG, telur, dan baking powder. Kemasan yang digunakan adalah kemasan kantong plastik polipropilen transparan dan plastik metalik dengan ukuran panjang $\mathrm{x}$ lebar $\mathrm{x}$ ketebalan berturutturut $26 \mathrm{~cm} \times 18 \mathrm{~cm} \times 130 \mu \mathrm{m}$ dan $26 \mathrm{~cm} \times 18 \mathrm{~cm} \times$ $110 \mu \mathrm{m}$.

Adapun bahan-bahan yang digunakan untuk pengujian adalah garam natrium nitrit/ $\mathrm{NaNO}_{2}$ (Merck), garam magnesium klorida/ $\mathrm{MgCl}_{2}($ Merck), garam potasium karbonat $/ \mathrm{K}_{2} \mathrm{CO}_{3}$ (Merck), garam natrium klorida/ $\mathrm{NaCl}$ (Merck), garam barium klorida/ $\mathrm{BaCl}_{2}$ (Merck), garam potasium sulfat/ $\mathrm{K}_{2} \mathrm{SO}_{4}$ (Merck) dan toluena (Merck).

\section{Pembuatan kerupuk ikan lele dumbo}

Garam, gula, rumput laut matang yang telah dihaluskan, MSG, minyak sayur, telur dan baking powder dicampur dengan daging ikan lele dumbo lumat, kemudian diaduk dalam mesin meat and kneading (Meidensha E4-CNR) selama \pm 5 menit. Tepung tapioka dan air sebanyak $\pm 1000 \mathrm{ml}$ ditambahkan sedikit demi sedikit kemudian diaduk kembali selama \pm 25 menit hingga membentuk adonan yang kalis (tidak lengket ditangan). Komposisi adonan kerupuk ikan lele dumbo dapat dilihat pada Tabel 1. Adonan dicetak dengan panjang 10-15 cm dan diameter 4-5 cm (Gambar 1a), kemudian dikukus selama 45 menit, didinginkan pada suhu kamar selama 18 jam, dipotong-potong dengan tebal $\pm 2 \mathrm{~mm}$ dan dijemur hingga kering.

Kerupuk mentah kering kemudian digiling tanpa penyaringan hingga menjadi butiran (krit) yang berukuran 0,4-2 mm (Gambar 1b). Pencetakan kerupuk tanpa goreng dilakukan dengan memasukkan 14 gram butiran (krit) ke dalam alat pemanggang kerupuk pada suhu $200^{\circ} \mathrm{C}$ selama \pm 15 detik hingga menjadi kerupuk panggang dengan diameter $\pm 12-15$ $\mathrm{cm}$ (Suryaningrum,Ikasari, Supriyadi, Intimulya \& Purnomo, 2016) (Gambar 1c). Kerupuk panggang sebanyak 5-6 keping dikemas dengan dua macam kemasan fleksibel yaitu PP dan plastik metalik. Diagram alir proses pembuatan kerupuk disajikan pada Gambar 2.

Tabel 1. Komposisi adonan kerupuk ikan lele dumbo Table 1. Dough composition of catfish crackers

\begin{tabular}{|c|c|c|}
\hline \multirow{2}{*}{ Bahan/ Materials } & \multicolumn{2}{|c|}{ Jumlah/Amount } \\
\hline & Gram & $(\%)^{*}$ \\
\hline Tepung tapioka/Tapioca flour & 3000 & 60.42 \\
\hline Daging lele lumat/Catfish mince meat & 1200 & 24.17 \\
\hline Rumput laut matang halus/Cooked seaweed paste & 60 & 1.21 \\
\hline Telur/Egg & 300 & 6.04 \\
\hline Gula/Sugar & 150 & 3.02 \\
\hline Soda kue/Baking powder & 30 & 0.61 \\
\hline Garam/Salt & 120 & 2.42 \\
\hline MSG & 15 & 0.30 \\
\hline Minyak sayur/Vegetable oil & 90 & 1.81 \\
\hline Jumlah/Total amount & 4965 & 100.00 \\
\hline
\end{tabular}

* persentase dari seluruh adonan/ percentage from total dough's weight

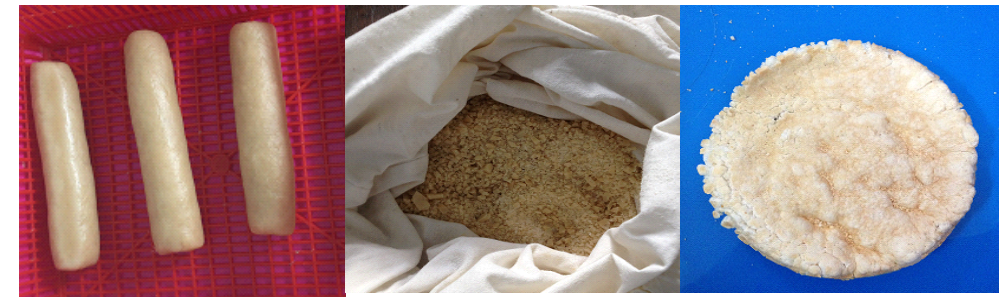

(a) (c)

Gambar 1. (a) Adonan kerupuk setelah pengukusan (b) butiran kerupuk (krit) (c) kerupuk lele dumbo panggang

Figure 1. (a) Crackers dough after steaming (b) crackers powder (krit)(c) roasted catfish crackers 


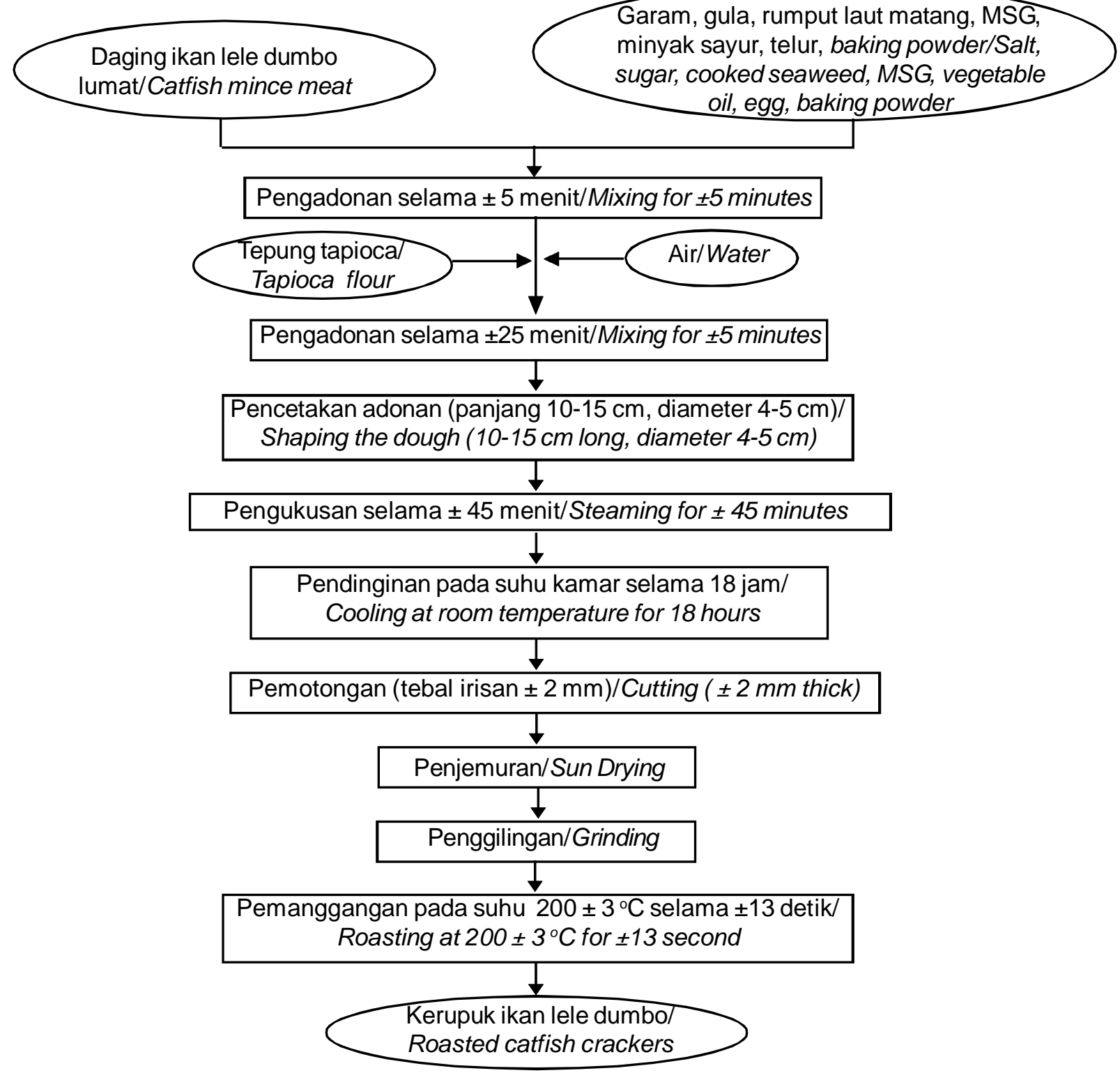

Gambar 2. Diagram alir pembuatan kerupuk ikan lele dumbo panggang

Figure 2. Flow chart of roasted catfish crackers processing

\section{Penentuan Umur Simpan}

Umur simpan kerupuk diduga dengan tahap penentuan kadar air kritis dan kadar air kesetimbangan. Kadar air kritis diperoleh dengan mengamati parameter kadar air, sensori nilai kerenyahan (SNI 2346: 2011), aktifitas air $\left(a_{w}\right)$ (Septianingrum, 2008) serta profil tekstur (Huda, Boni, \& Noryati, 2009) kerupuk ikan lele dumbo panggang tanpa kemasan pada kondisi suhu ruang $30 \pm 2^{\circ} \mathrm{C}$ dan $\mathrm{RH} 55 \pm 2 \%$ selama 3 jam dengan waktu pengamatan $0,30,60,90,120,150$ dan 180 menit.
Profil tekstur diukur dengan menggunakan Stable Micro System Texture Analyzer XT Plus (SMS TAXT Plus) dengan diameter jarum $6 \mathrm{~mm}$ tipe $\mathrm{P} / 6$. Skor 2 (tidak renyah) pada lembar uji sensori ditetapkan sebagai batas penolakan panelis terhadap kerupuk ikan lele dumbo panggang (Tabel 2) (Syarif \& Halid, 1993). Nilai sensori kerenyahan kemudian dimasukan dalam persamaan linear sebagai sumbu $x$ dengan nilai kadar air sebagai sumbu y untuk memperoleh nilai kadar air pada saat skor sensori kerenyahan memiliki nilai 2 (batas kritis) (Histifarina, 2015; Syarif \& Halid, 2003; ). Sensori dilakukan oleh 21 orang panelis 
Pendugaan Umur Simpan Kerupuk Ikan Lele Dumbo (Clarias gariepenus) panggang.........(Diah Ikasari et al.,)

Tabel 2. Skor uji sensori terhadap parameter kerenyahan kerupuk ikan lele dumbo panggang Table2. Score of sensory evaluation on parameter of crispness catfish roasted crackers

\begin{tabular}{cc}
\hline & Skor Kerenyahan/ Crispness Score \\
\hline 1 & Tidak renyah/Not crispy \\
2 & Sedikit renyah/Slightly crispy \\
3 & Renyah/Crispy \\
4 & Sangat renyah/Very crispy \\
\hline
\end{tabular}

terlatih. Penegasan tercapainya kadar air kritis juga dilakukan dengan menggunakan Scanning Electron Microscopy (JEOL JCM-6000) terhadap kenampakan melintang miroskopik kerupuk ikan lele dumbo panggang pada awal pengamatan (titik ke-0) dan pada saat mencapai kadar air kritis (Suryaningrum, Ikasari, Supriyadi, Intimulya, \& Purnomo, 2016).

Nilai kadar air setimbang diperoleh dengan cara memasukkan larutan garam jenuh ke dalam toples kedap udara yang digunakan untuk menyimpan sampel. Larutan garam jenuh dibuat dengan cara melarutkan garam $\mathrm{MgCl}_{2}, \mathrm{~K}_{2} \mathrm{CO}_{3}, \mathrm{NaNO}_{2}, \mathrm{NaCl}, \mathrm{BaCl}_{2}$ dan $\mathrm{K}_{2} \mathrm{SO}_{4}$ dalam aquades hingga jenuh atau tidak larut sehingga diperoleh Relative Humidity $(\mathrm{RH})$ yang berbeda-beda. Sebanyak $2 \mathrm{~g}$ sampel kerupuk panggang disimpan ke dalam toples kedap udara yang berisi larutan garam jenuh tersebut kemudian disimpan pada suhu ruang $30 \pm 2^{\circ} \mathrm{C}$. Kerupuk panggang tersebut ditimbang secara periodik setiap 24 jam hingga tercapai bobot yang setimbang. Kerupuk panggang yang telah mencapai bobot konstan dianalisis kadar airnya (kadar air setimbang). Kadar air setimbang diperoleh saat kadar air kerupuk ikan lele dumbo panggang telah seimbang dengan $\mathrm{RH}$ yang terdapat pada lingkungan. Hal ini ditandai dengan bobot yang konstan selama tiga kali penimbangan berturut-turut yakni sebesar $\leq 2 \mathrm{mg}$ untuk $\mathrm{RH}<90 \%$ dan $\leq 10 \mathrm{mg}$ untuk $\mathrm{RH}>90 \%$. Kelembaban $(\mathrm{RH})$ larutan garam jenuh yang berbeda digunakan untuk menentukan titiktitik kurva sorpsi isotermis yang paling tepat dalam menentukan umur simpan kerupuk ikan lele dumbo panggang. Kadar air kesetimbangan kemudian dimasukkan dalam beberapa model persamaan kurva sorpsi isothermis untuk memperoleh koefisien korelasi kurva yang tinggi (Tabel 3 ).

Tabel 3. Model persamaan kurva sorpsi isothermis

Table 3. Equation model of isothermis sorption curve

\begin{tabular}{|c|c|c|}
\hline Model/ Model & Persamaan/ Equation & Linear $y=b x+a /$ Linear $y=b x+a$ \\
\hline Oswin & $\mathrm{Me}=\mathrm{P}_{1}\left(\mathrm{a}_{\mathrm{w}} /\left(1-\mathrm{a}_{\mathrm{w}}\right)\right)^{\mathrm{P} 2}$ & $\ln \mathrm{Me}=\ln \mathrm{P} 1+\mathrm{P} 2 \ln \left(\mathrm{a}_{\mathrm{w}} /\left(1-\mathrm{a}_{\mathrm{w}}\right)\right)$ \\
\hline Halsey & $a_{w}=\exp \left(-P_{1} /(M e)^{P 2}\right)$ & $\log \left(\ln \left(1 / \mathrm{a}_{w}\right)\right)=\log (\mathrm{P} 1-\mathrm{P} 2) \log \mathrm{Me}$ \\
\hline Henderson & $1-a_{w}=\exp \left(-K \cdot M e^{n}\right)$ & $\log \left(\ln \left(1 /\left(1-a_{w}\right)\right)\right)=\left(\log M e^{*} \log K\right)+n$ \\
\hline C.Clayton & $a_{w}=\exp \left(-P_{1} / \exp \left(P_{2}^{*} M e\right)\right)$ & $\ln \left(\ln \left(1 / \mathrm{a}_{\mathrm{w}}\right)\right)=\ln (\mathrm{P} 1-\mathrm{P} 2) \mathrm{Me}$ \\
\hline Caurie & $\ln \mathrm{Me}=\ln \left(\mathrm{P}_{1}-\mathrm{P}_{2}\right)^{*} \mathrm{a}_{\mathrm{w}}$ & $\ln \mathrm{Me}=\ln \mathrm{P} 1-\mathrm{P} 2 \mathrm{a}_{\mathrm{w}}$ \\
\hline \multirow{6}{*}{ GAB } & A.B.C. $a_{w}$ & \\
\hline & $\left(1-B \cdot a_{w}\right)\left(1-B \cdot a_{w}+B \cdot C \cdot a_{w}\right)$ & \\
\hline & $y=\alpha x^{2}+\beta x+\gamma \sim\left(a_{w} / M e\right)=\alpha\left(a_{w}\right)^{2}+\beta a_{w}+y$ & \\
\hline & $\alpha=C / A((1 / B)-1) ; \beta=1 / A(1-(2 / B) ; \gamma=1 /(A \cdot B . C)$ & \\
\hline & $T=\left(\beta^{2} /(-\alpha . \gamma)\right)+4$ & \\
\hline & $B=\left(T+\left(T^{2}-4 T\right)^{1 / 2}\right) / 2 ; A=(1-(2 / C)) \cdot(1 / \beta) ; C=1 /(B . A . Y)$ & \\
\hline
\end{tabular}


Persamaan-persamaan kurva sorpsi isotermis di uji ketepatannya dengan menghitung nilai MRD. Jika nilai MRD $<5$ maka model sorpsi isotermis dapat menggambarkan keadaan yang sebenarnya atau sangat tepat. Model sorpsi isotermis dengan $5<$ MRD $<10$ menunjukkan bahwa model tersebut agak tepat meggambarkan keadaan sebenarnya dan jika MRD $>10$ maka model tersebut tidak tepat menggambarkan kondisi sebenarnya (Budijanto, Sitanggang, \& Kartika, 2010).

$$
|M R D|=\frac{100 \sum_{i}^{n}}{n}=1 \quad \frac{M i-M p i}{M i}
$$

Keterangan/Notes:

$$
\begin{aligned}
\mathrm{Mi}= & \text { Kadar air percobaan/Experimental moisture } \\
& \begin{array}{l}
\text { content } \\
\mathrm{Mpi}=
\end{array} \\
& \begin{array}{l}
\text { Kadar air hasil perhitungan/Calculation moisture } \\
\text { content }
\end{array} \\
\mathrm{n}= & \text { Jumlah data/Sum of data }
\end{aligned}
$$

Selain parameter-parameter di atas, dilakukan pula pengukuran terhadap variabel-variabel pendukung yang digunakan dalam persamaan Labuza antara lain : permeabilitas kemasan terhadap uap air $(\mathrm{k} / \mathrm{x})$; luas permukaan kemasan $(A)$; berat padatan per kemasan (Ws) dan tekanan uap jenuh penyimpanan (Po), yakni pada suhu $30^{\circ} \mathrm{C}$ (Septianingrum, 2008). Penentuan permeabilitas kemasan dilakukan dengan menggunakan pengukur permeabilitas gas (Perme Labthink W3/030). Pada pengukuran dengan alat ini diperoleh nilai laju perpindahan uap air yang melalui kemasan/Water Vapor Transmission Rate(WVTR) (g/ $\mathrm{m}^{2} /$ hari/RH). Nilai permeabilitas kemasan terhadap uap air $(\mathrm{k} / \mathrm{x})$ dalam satuan $\mathrm{g} / \mathrm{m}^{2}$.hari. $\mathrm{mmHg}$ selanjutnya ditentukan dengan membagi nilai WVTR dengan perbedaan tekanan $(\Delta \mathrm{P})$. Tekanan uap jenuh penyimpanan merupakan tekanan uap murni pada suhu $30^{\circ} \mathrm{C}(\mathrm{Po})$ yaitu sebesar 31.82 yang diperoleh dari Tabel Labuza; sedangkan nilai luas penampang (A) diperoleh dengan mengalikan dimensi panjang dan lebar kemasan dan dinyatakan dalam satuan meter persegi $\left(\mathrm{m}^{2}\right)$. Nilai total padatan (Ws) diperoleh dengan mengoreksi berat keseluruhan kerupuk dikurangi dengan kadar air awal. Bobot kerupuk dalam satu kemasan ditimbang dan dikoreksi dengan kadar airnya kemudian dinyatakan sebagai bobot padatan per kemasan dengan persamaan sebagai berikut :

$$
\mathrm{Ws}=\mathrm{W}^{*}(\% \text { solid } / 100) \text { dengan } \% \text { solid }=\left(1-(\mathrm{mo} /(1+\mathrm{mo})){ }^{*} 100\right.
$$

Semua parameter yang diukur dan ditetapkan yakni meliputi: Mi, Mc, Me, k/x, Po, b, A dan Ws diintegrasikan ke dalam persamaan Labuza (1982) untuk pendugaan umur simpan yaitu sebagai berikut:

$$
\Theta=\frac{\ln \frac{(M e-M i)}{(M e-M c)}}{\frac{k}{x}(\underline{A}) \underline{P o}}
$$

$\Theta=$ Waktu perkiraan umur simpan (hari)/Shelf life prediction time (day)

$\mathrm{Me}=\mathrm{Kadar}$ air keseimbangan produk $\left(\mathrm{g} \mathrm{H}_{2} \mathrm{O} / \mathrm{g}\right.$ padatan $) /$ Equilibrium moisture content of product $\left(\mathrm{g} \mathrm{H}_{2} \mathrm{O} / \mathrm{g}\right.$ solid)

$\mathrm{Mi}=$ Kadar air awal produk $\left(\mathrm{g} \mathrm{H}_{2} \mathrm{O} / \mathrm{g}\right.$ padatan $) /$ Initial moisture content of product $\left(\mathrm{g} \mathrm{H}_{2} \mathrm{O} / \mathrm{g}\right.$ solid)

b = Slove kurva sorpsi isotermis/Slope of Isotherm sorption curve

$\mathrm{Mc}=\mathrm{Kadar}$ air kritis $\left(\mathrm{g} \mathrm{H}_{2} \mathrm{O} / \mathrm{g}\right.$ padatan)/Critical moisture content ( $\mathrm{g} \mathrm{H}_{2} \mathrm{O} / \mathrm{g}$ solid)

$\mathrm{k} / \mathrm{x}=$ Permeabilitas uap air kemasan $\left(\mathrm{g} / \mathrm{m}^{2}\right.$.hari.mmHg $) /$ Moisture permeability of packaging ( $g /$ $m^{2}$.day. $\mathrm{mmHg}$ )

$A=$ Luas permukaan kemasan $\left(\mathrm{m}^{2}\right) /$ Packaging area $\left(m^{2}\right)$

$W s=$ Berat kering produk dalam kemasan (g padatan)/ Product dry weight in packaging ( $g$ solid)

$P_{0}=$ Tekanan uap jenuh $(\mathrm{mmHg}) /$ Saturated steam pressure $(\mathrm{mmHg})$

\section{HASIL DAN BAHASAN}

\section{Kadar air kritis (Mc)}

Hasil pengamatan selama 180 menit terhadap skor kerenyahan, nilai $\mathrm{a}_{\mathrm{w}}$ dan kadar air kerupuk ikan lele dumbo panggang disajikan pada Tabel 4, sedangkan profil tekstur disajikan pada Tabel 5 . Nilai $\mathrm{a}_{\mathrm{w}}$ dan profil tekstur kerupuk ikan lele dumbo panggang diamati untuk mengetahui batas nilainya saat panelis mulai menyatakan bahwa kerupuk tidak lagi renyah/kurang renyah (batas kritis). Kadar air produk kering memiliki hubungan erat dengan nilai $a_{w}$ dan profil tekstur. Secara umum, nilai $\mathrm{a}_{w}$ berkorelasi positif dengan kadar air; semakin tinggi jumlah total kandungan air suatu bahan dapat terjadi karena semakin tingginya jumlah air bebas yang terkandung dalam bahan pangan tersebut. Sedangkan data profil tekstur terdiri dari beberapa parameter, yaitu kekerasan (hardness), kerenyahan (fracturability), daya kohesif (cohesiveness), sifat adesif (adhesiveness), elastisitas (springiness), kelengketan (gumminess), daya kunyah (chewiness) dan tingkat kekenyalan (resilience). Namun demikian untuk produk kerupuk panggang nilai kekerasan dan kerenyahan menjadi parameter utama. Nilai kekerasan dan kerenyahan berdasarkan analisis profil tekstur saling berkorelasi 
Pendugaan Umur Simpan Kerupuk Ikan Lele Dumbo (Clarias gariepenus) panggang.........(Diah Ikasari et al.,)

Tabel 4. Nilai $\mathrm{a}_{\mathrm{w}}$ dan kadar air $\left(\mathrm{g} \mathrm{H}_{2} \mathrm{O} / \mathrm{g}\right.$ padatan) berdasarkan sensori kerupuk ikan lele dumbo selama 180 menit pengamatan.

Table 4. $a_{w}$ value and moisture content $\left(\mathrm{g} \mathrm{H}_{2} \mathrm{O} / \mathrm{g}\right.$ solid) based on sensory results of catfish roasted crackers during 180 minutes observation

\begin{tabular}{|c|c|c|c|}
\hline $\begin{array}{c}\text { Pengamatan ke- (menit)/ } \\
\text { Time of Observation (minutes) }\end{array}$ & $\begin{array}{l}\text { Skor Kerenyahan/ } \\
\text { Crispness score }\end{array}$ & Nilai $a_{w} / a_{w}$ values & $\begin{array}{c}\text { Kadar air }\left(\mathrm{g} \mathrm{H}_{2} \mathrm{O} / \mathrm{g} \text { padatan }\right) / \\
\text { Moisture content }\left(\mathrm{g} \mathrm{H}_{2} \mathrm{O} / \mathrm{g} \text { solid) }\right.\end{array}$ \\
\hline 0.00 & 3.51 & 0.18 & 0.02 \\
\hline 30.00 & 1.93 & 0.39 & 0.06 \\
\hline 60.00 & 1.77 & 0.41 & 0.06 \\
\hline 90.00 & 1.55 & 0.43 & 0.07 \\
\hline 120.00 & 1.53 & 0.44 & 0.07 \\
\hline 150.00 & 1.28 & 0.46 & 0.08 \\
\hline 180.00 & 1.10 & 0.48 & 0.08 \\
\hline
\end{tabular}

Tabel 5. Profil tekstur kerupuk ikan lele dumbo panggang selama 180 menit pengamatan

Table 5. Texture profile of catfish roasted crackers during 180 minutes observation

\begin{tabular}{|c|c|c|c|c|c|c|c|c|}
\hline $\begin{array}{c}\text { Pengamatan } \\
\text { ke-/ } \\
\text { Time of } \\
\text { Observation } \\
\text { (menit/ } \\
\text { minutes) }\end{array}$ & $\begin{array}{l}\text { Kekerasan } \\
\text { /Hardness } \\
\text { (N) }\end{array}$ & $\begin{array}{l}\text { Daya patah/ } \\
\text { Fracturability } \\
\text { (N) }\end{array}$ & $\begin{array}{c}\text { Daya kohesif/ } \\
\text { Cohesiveness } \\
\text { (\%) }\end{array}$ & $\begin{array}{c}\text { Kelengketan/ } \\
\text { Gumminess }\end{array}$ & $\begin{array}{c}\text { Daya } \\
\text { kunyah/ } \\
\text { Chewiness }\end{array}$ & $\begin{array}{c}\text { Kekenyalan/ } \\
\text { Resilience } \\
\text { (\%) }\end{array}$ & $\begin{array}{c}\text { Sifat adesif/ } \\
\text { Adhesivness } \\
\text { (g.sec) }\end{array}$ & $\begin{array}{c}\text { Bastisitas/ } \\
\text { Springiness } \\
\text { (\%) }\end{array}$ \\
\hline 0 & 11.34 & 11.51 & 0.11 & 146.66 & 133.08 & 0.06 & -16.81 & 0.88 \\
\hline 30 & 18.34 & 18.08 & 0.15 & 273.69 & 243.56 & 0.07 & -12.39 & 0.89 \\
\hline 60 & 20.46 & 21.23 & 0.15 & 314.26 & 275.06 & 0.07 & -11.53 & 0.90 \\
\hline 90 & 18.91 & 20.54 & 0.16 & 327.50 & 271.68 & 0.07 & -5.18 & 0.85 \\
\hline 120 & 21.67 & 23.49 & 0.13 & 270.04 & 234.93 & 0.06 & -22.31 & 0.90 \\
\hline 150 & 22.81 & 22.88 & 0.12 & 274.92 & 224,17 & 0.06 & -10.69 & 0.84 \\
\hline 180 & 26.07 & 25.95 & 0.14 & 368.84 & 302.90 & 0.07 & -3.58 & 0.83 \\
\hline
\end{tabular}

negatif. Nilai kekerasan dan kerenyahan yang terhitung pada analisis profil tekstur adalah tekanan yang diberikan oleh alat untuk dapat memecahkan produk sehingga semakin tinggi nilai kekerasan dalam analisis profil tekstur mengindikasikan produk semakin tidak renyah.

Berdasarkan Tabel 4 panelis menyatakan skor ratarata 1,93 pada menit ke-30, yang menunjukkan bahwa kerupuk ikan lele dumbo panggang sedikit renyah (lebih rendah dari skor 2 pada skor kerenyahan). Dengan demikian nilai skor $2(x=2)$ ditentukan sebagai subtitusi terhadap persamaan linear yang diperoleh berdasarkan Tabel 4 dan 5. Persamaan linear serta hasil penentuan waktu, kadar air, $a_{w}$, kekerasan dan daya patah berdasarkan sensori kerupuk ikan lele dumbo panggang disajikan pada Tabel 6.
Nilai $\mathrm{a}_{\mathrm{w}}$, tingkat kekerasan dan daya patah profil tekstur kerupuk ikan lele dumbo panggang dalam kondisi kritis atau telah dinyatakan tidak lagi renyah oleh panelis $(x=2)$ berturut-turut adalah $0,376,18,920$ $\mathrm{N}$ dan 19,456 $\mathrm{N}$ berdasarkan perhitungan dari persamaan linear dengan axis berupa skor sensori kerenyahan (Tabel 5). Kadar air kritis ditentukan dari nilai terendah untuk mewaspadai adanya kemungkinan kondisi penyimpanan yang tidak sesuai pada saat distribusi produk yakni berdasarkan skor kerenyahan. Hasil perhitungan terhadap kadar air kritis menunjukkan bahwa kerupuk ikan lele dumbo dapat dikatakan mencapai kadar air kritis sebesar 0,0538 g $\mathrm{H}_{2} \mathrm{O} / \mathrm{g}$ padatan setelah 76 menit berdasarkan pada persamaan linear data hasil skor kerenyahan.

Perbedaan profil tekstur kerupuk pada kondisi renyah dan pada saat mencapai kondisi batas kritis 
Tabel 6. Persamaan linear serta hasil penentuan waktu, kadar air, $a_{w}$, kekerasan dan daya patah berdasarkan sensori kerupuk ikan lele dumbo panggang.

Table 6. Linear equation and determination of time, moisture content, $a_{w^{\prime}}$ hardness and fracturability based on sensory of catfish roasted crackers

\begin{tabular}{|c|c|c|c|}
\hline Parameter/Parameters & $\begin{array}{c}\text { Persamaan Linear }(\mathrm{x}=\text { skor } \\
\text { kerenyahan }) / \\
\text { Linear equation }(\mathrm{x}=\text { score of } \\
\text { crispness })\end{array}$ & $\begin{array}{l}\text { Nilai } R^{2} / \\
R^{2} \text { value }\end{array}$ & $y(x=2)$ \\
\hline Waktu (menit)/Time (minutes) & $Y=-68.56 x+214.1$ & 0.72 & 76 \\
\hline $\begin{array}{l}\text { Kadar air kritis (log) }\left(\mathrm{g} \mathrm{H}_{2} \mathrm{O} / \mathrm{g}\right. \\
\text { padatan }) / \text { Critical moisture content } \\
\left(\mathrm{g} \mathrm{H}_{2} \mathrm{O} / \mathrm{g} \text { solid) }\right.\end{array}$ & $Y=-0.235 x-0.799$ & 0.98 & 0.0538 \\
\hline Nilai $a_{w} / a_{w}$ value & $Y=-0.128 x+0.632$ & 0.99 & 0.376 \\
\hline Kekerasan/Hardness & $Y=-5.450 x+29.82$ & 0.90 & 18.920 \\
\hline Daya patah/Fracturability & $Y=-5.622 x+30.70$ & 0.92 & 19.456 \\
\hline
\end{tabular}

disajikan pada Gambar 3. Pada bukit pertama profil tekstur, puncak pertama mewakili nilai kerenyahan sedangkan puncak tertinggi mewakili nilai kekerasan. Pada kondisi batas kritis nilai kekerasan dan nilai daya patah lebih tinggi karena kerupuk panggang dalam kondisi "melempem" atau bersifat elastis sehingga tidak mudah patah (Anon, 2017). Lingkungan yang memiliki RH tinggi mengakibatkan kerupuk akan lebih cepat menyerap air dari lingkungan sebagai reaksi untuk menuju kondisi keseimbangan yang akan menyebabkan kerupuk menjadi melempem. Semakin renyah kerupuk maka daya tekan yang terukur pada

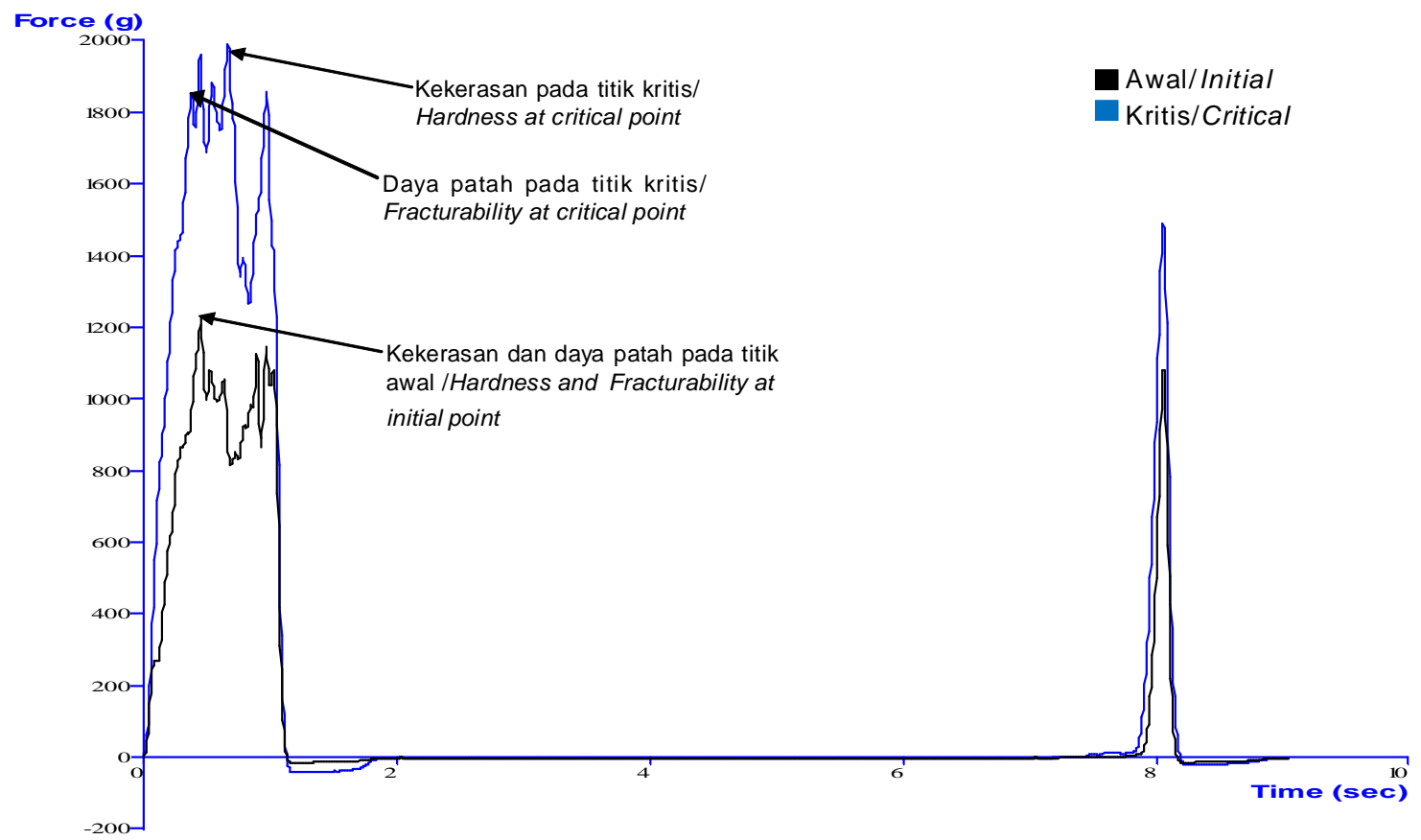

Gambar 3. Profil tekstur kerupuk ikan lele dumbo panggang pada kondisi awal dan kritis

Figure 3. Texture profile of catfish roasted crackers at the initial and critical condition 


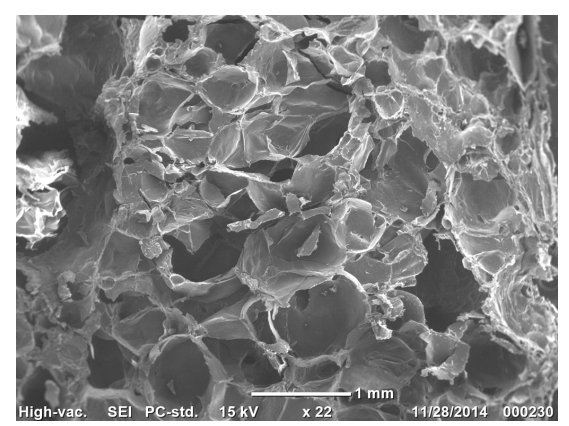

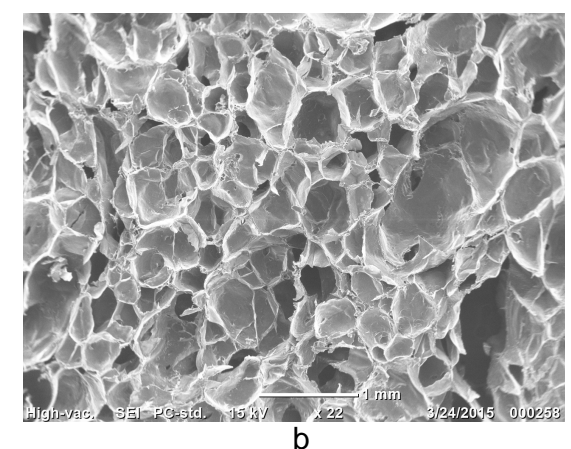

b

Gambar 4. Kenampakan melintang mikroskopik kerupuk ikan lele dumbo panggang pada berbagai kondisi. Kenampakan bagian tengah (a) pada kondisi awal $\left(\mathrm{a}_{\mathrm{w}} 0,18\right)$; dan (b) pada kondisi kritis $\left(\mathrm{a}_{\mathrm{w}} 0,39\right)$.

Figure 4. Microscopic cross-section of catfish roasted crackers at various conditions. Middle part section (a) at initial condition $\left(a_{w}, 18\right)$ and $(b)$ at critical condition $\left(a_{w} 0,39\right)$.

tingkat kekerasan dan tingkat kerenyahan profil tekstur bermilai semakin rendah.

Perubahan akibat penyerapan uap air pada kerupuk juga dapat dilihat kenampakan mikroskopis kerupuk ikan lele dumbo panggang (Gambar 4). Kenampakan melintang mikroskopik kerupuk ikan lele dumbo panggang pada kondisi awal dan kritis. Pada kondisi kritis (Gambar 4b), ukuran pori-pori kerupuk mulai mengalami penyusutan. Air akan melarutkan dan melunakkan matriks pati dan protein yang ada pada sebagian bahan pangan sehingga mengakibatkan perubahan kekuatan mekanik termasuk kerenyahan (Labuza, 1982).

\section{Kadar Air Kesetimbangan (Me)}

Selama penyimpanan produk dalam berbagai larutan garam jenuh terjadi proses kesetimbangan air yakni produk menyerap air dari lingkungan (adsorpsi) dan lingkungan yang menyerap air dari dalam bahan (desorpsi). Proses adsorpsi terjadi pada $\mathrm{RH}$ tinggi dan sebaliknya proses desorpsi terjadi pada $\mathrm{RH}$ yang rendah. Perpindahan uap air disebabkan oleh perbedaan kelembaban relatif sehingga uap air bergerak dari $\mathrm{RH}$ tinggi menuju $\mathrm{RH}$ rendah. Grafik hubungan aktivitas air dengan kadar air kesetimbangan pada berbagai perlakuan kerupuk ikan lele dumbo panggang disajikan pada Gambar 5. Peningkatan

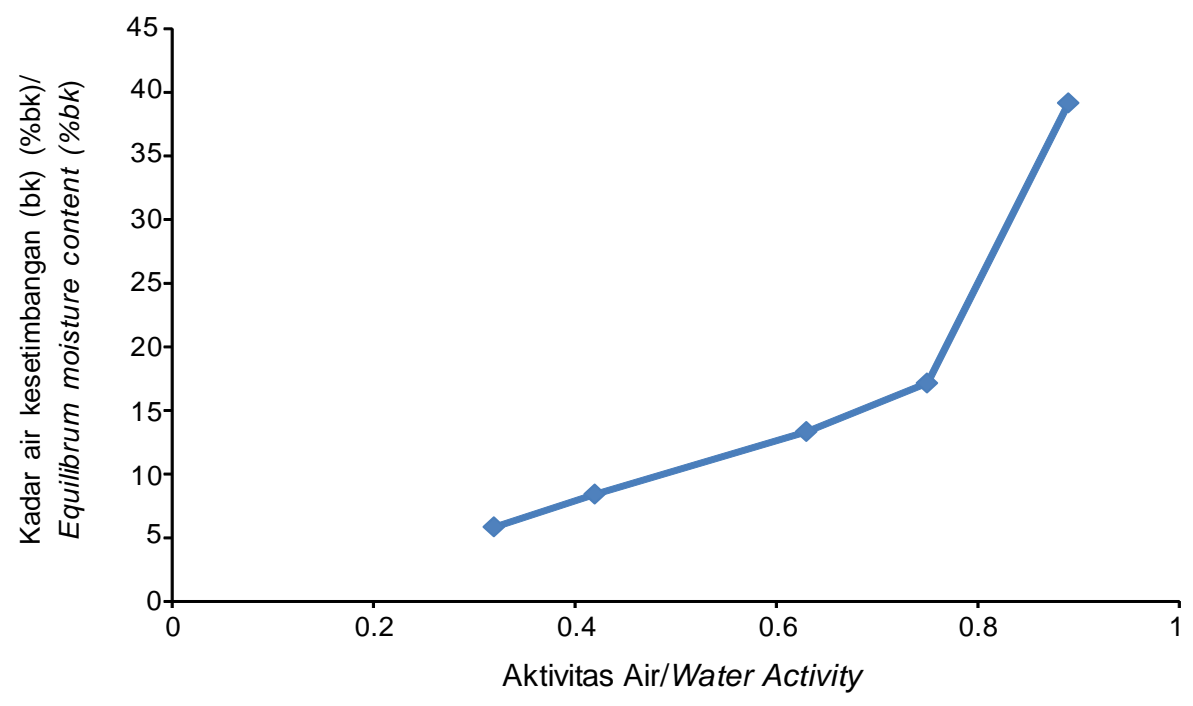

Gambar 5.Grafik hubungan aktivitas air dengan kadar air kesetimbangan

Figure 5. Relationship graph between water activity and equilibrium moisture content 
aktivitas air/RH penyimpanan menyebabkan peningkatan kadar air kesetimbangan. Fenomena sorpsi isotermis tersebut menggambarkan proses kesetimbangan antara $\mathrm{RH}$ lingkungan yang dihasilkan oleh larutan garam jenuh dengan aktivitas air kerupuk ikan lele dumbo panggang pada suhu $30^{\circ} \mathrm{C}$. Kerupuk ikan lele dumbo panggang mencapai kadar air kesetimbangan tersebut dalam waktu 3-4 minggu.

\section{Penentuan model kurva sorpsi isotermis untuk produk kerupuk ikan lele dumbo panggang}

Kadar air kesetimbangan selanjutnya disubtitusikan ke dalam model-model persamaan Oswin, Halsey, Henderson, Chen \& Clayton, Caurie, dan Guggenheim, Anderson \& De Boer (GAB) untuk memperoleh nilai kemulusan kurva yang tinggi, serta dihitung nilai MRD untuk menentukan ketepatan model persamaan sorpsi isotermis. Hasil persamaan dan nilai MRD kerupuk ikan lele dumbo panggang disajikan pada Tabel 7.

Tabel 7 menunjukkan bahwa nilai MRD model persamaan Halsey paling tepat di antara model persamaan Oswin, Halsey, Henderson, Chen \& Clayton, Caurie, dan Guggenheim, Anderson \& De Boer (GAB) dalam menggambarkan fenomena sorpsi kerupuk ikan lele dumbo panggang dengan nilai 5,75 dengan nilai kemulusan kurva sorpsi isotermis terbaik (Gambar 6b). Model kurva sorpsi isotermis memiliki ketepatan model yang baik jika nilai $M R D<10 \%$ (McMinn \& Magee, 2003).

Kemulusan kurva yang tinggi dapat juga ditunjukkan dengan semakin berhimpitnya kurva sorpsi isotermis hasil penelitian dan kurva sorpsi isotermis hasil perhitungan dari berbagai model persamaaan (Gambar 6). Model persamaan Halsey memiliki nilai MRD terendah dan himpitan kurva sorpsi isotermis terkecil.

Model persamaan Halsey paling tepat digunakan di antara model persamaan Oswin, Halsey, Henderson, Chen \& Clayton, Caurie, dan Guggenheim, Anderson \& De Boer (GAB) dalam menggambarkan fenomena sorpsi kerupuk ikan lele dumbo panggang karena memiliki nilai MRD terkecil. Dari persamaan model terpilih dapat diperoleh nilai slope (b). Titik-titik hubungan antara aktivitas air dan kadar air kesetimbangan memiliki persamaan linear $(y=b x+a)$ dan slope kurva sorpsi isotermis adalah nilai b pada persamaan tersebut (Faridah, Yasni, Suswantinah, \& Aryani, 2013). Slope kurva sorpsi isotermis kerupuk ikan lele dumbo pada model persamaan terpilih (Halsey) adalah 0,508 (Gambar 7).

Hal ini juga sesuai dengan hasil study Trinoviyani (2015) yang melaporkan bahwa pemodelan isoterm sorpsi air pada cabai rawit bubuk fermentasi adalah model Halsey dengan nilai MRD sebesar 4,70 dengan umur simpan 78 hari berdasarkan persamaan Labuza. Model Halsey juga merupakan persamaan yang paling tepat menggambarkan data sorpsi isotherm air pada aprikot, apel dan kentang pada suhu 30, 45 dan $60^{\circ} \mathrm{C}$ (Kaymak-Ertekin \& Gedik, 2004).

\section{Variabel pendukung}

Variabel lain dalam penentuan umur simpan selain yang telah ditentukan di atas adalah permeabilitas kemasan terhadap uap air $\left(\mathrm{g} / \mathrm{m}^{2}\right.$.hari. $\left.\mathrm{mmHg}\right)$, luas kemasan dalam satuan $\mathrm{m}^{2}$, berat padatan per kemasan dan tekanan uap jenuh penyimpanan yakni

Tabel 7. Model persamaan kurva sorpsi isotermis kerupuk ikan lele dumbo panggang

Table 7. The equation model isotherm sorption curve of roasted catfish crackers

\begin{tabular}{lccc}
\hline $\begin{array}{l}\text { Model Persamaan/ } \\
\text { Equation model }\end{array}$ & Persamaan/ Equation & $\begin{array}{c}\text { Nilai } \mathbf{R}^{2} / \\
\mathbf{R}^{2} \text { value }\end{array}$ & $\begin{array}{c}\text { Nilai MRD/ } \\
\text { MRD value }\end{array}$ \\
\hline Oswin (1946) & $\ln \mathrm{Me}=0,637 \ln \left(\mathrm{a}_{\mathrm{w}} /\left(1-\mathrm{a}_{\mathrm{w}}\right)\right)-2,342$ & 0.98 & 5.92 \\
Halsey (1948) & $\log \left(\ln \left(1 / \mathrm{a}_{\mathrm{w}}\right)\right)=-1,246 \log \mathrm{Me}-1,448$ & 0.99 & $\mathbf{5 . 7 5}$ \\
Henderson (1952) & $\log \left(\ln \left(1 /\left(1-\mathrm{a}_{\mathrm{w}}\right)\right)\right)=0,948 \log \mathrm{Me}+0,786$ & 0.96 & 11.93 \\
Chen \& Clayton (1971) $\ln \left(\ln \left(1 / \mathrm{a}_{\mathrm{w}}\right)\right)=-6,571 \mathrm{Me}+0,267$ & 0.91 & 29.88 \\
Caurie (1981) & $\ln \mathrm{Me}=3,039 \mathrm{a}_{\mathrm{w}}-3,835$ & 0.95 & 12.17 \\
GAB (1981) & $\mathrm{a}_{\mathrm{w}} / \mathrm{Me}=-13,48 \mathrm{a}_{\mathrm{w}}{ }^{2}+11,50 \mathrm{a}_{\mathrm{w}}+2,914$ & 0.93 & 6.45 \\
\hline
\end{tabular}



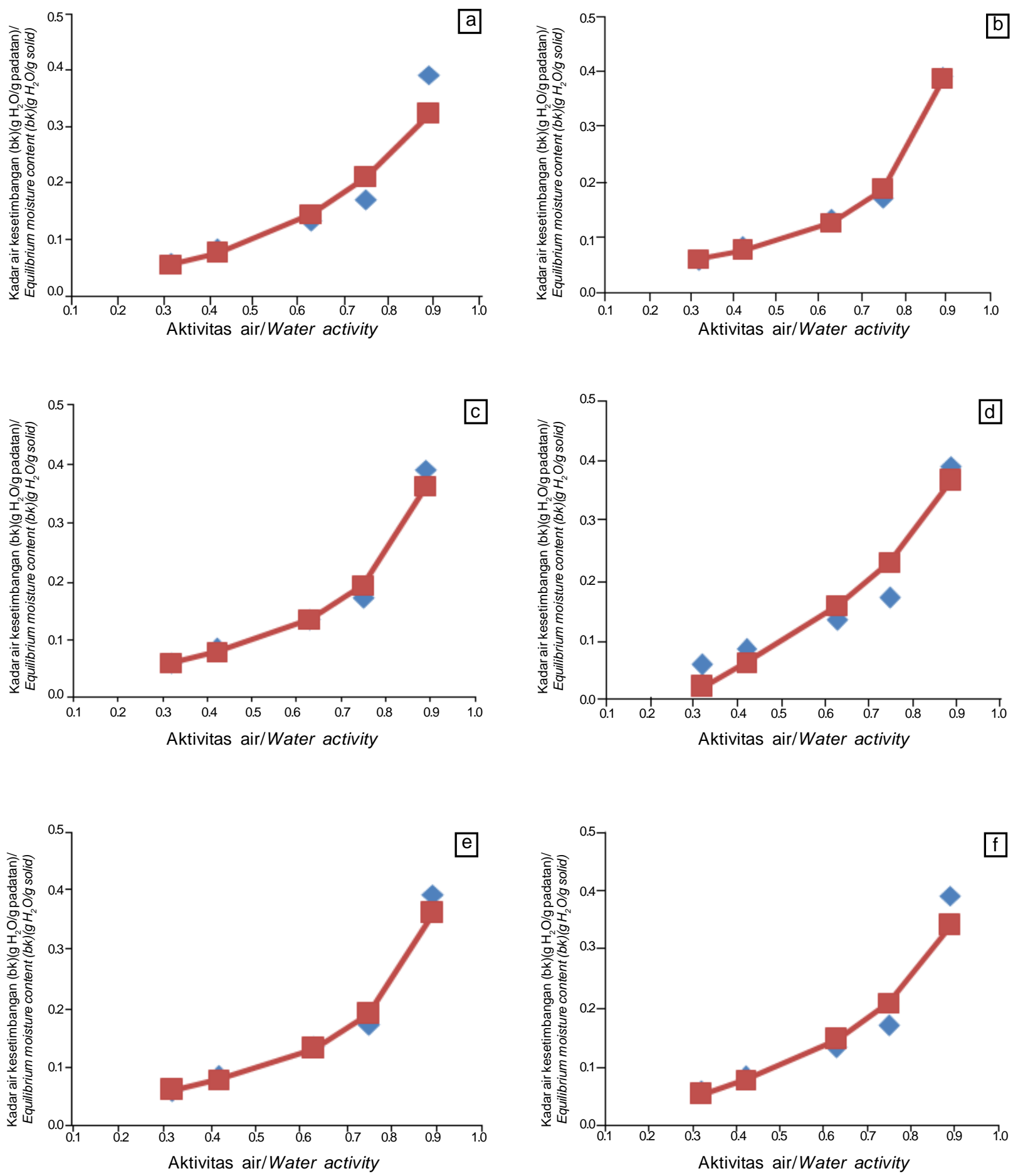

- Hasil penelitian/Observation result

$\rightarrow-$ Hasil perhitungan/Calculation result

Gambar 6. Kurva sorpsi isotermis kadar air setimbang hasil penelitian dan perhitungan model terpilih pada kerupuk ikan lele dumbo panggang. a) Caurie, b) Halsey, c) Oswin, d) Chen \& Clayton, e) Guggenheim, Anderson \& De Boer, f) Henderson.

Figure 6. Isotherm sorption curve of equilibrium moisture content resulted from observation and calculation of certain model of roasted catfish crackers. a) Caurie, b) Halsey, c) Oswin, d) Chen \& Clayton, e) Guggenheim, Anderson \& De Boer, f) Henderson. 


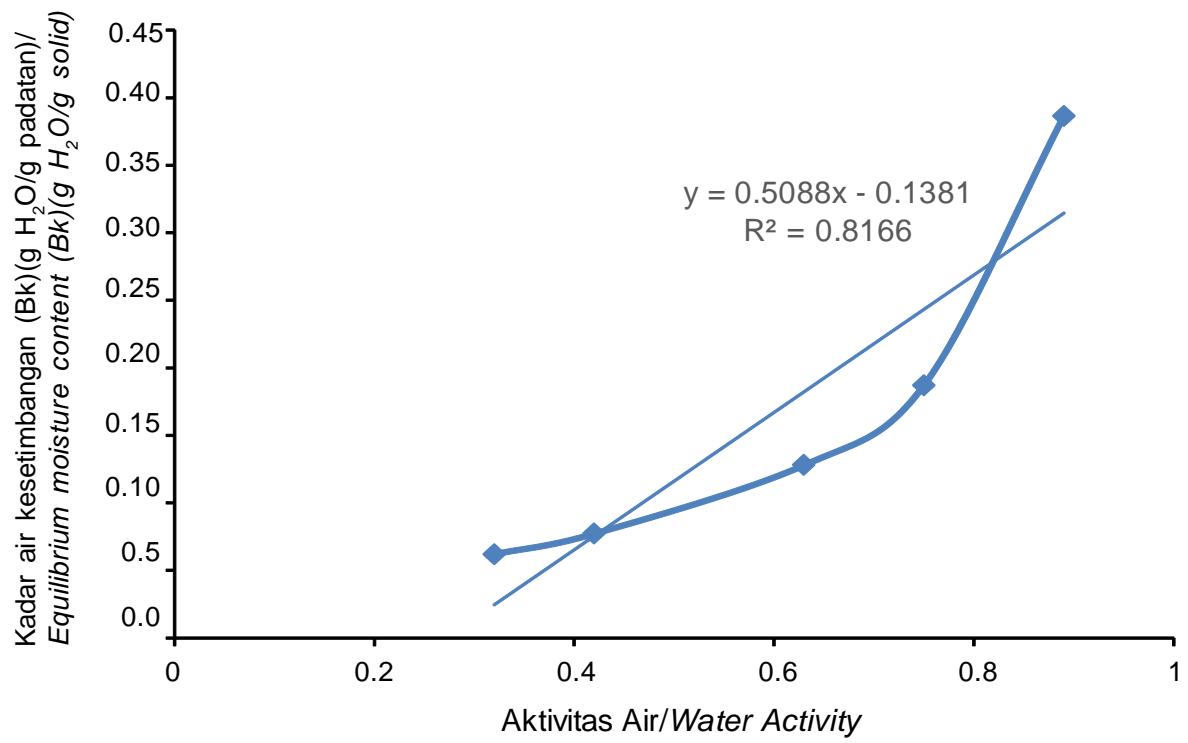

Gambar 7. Penentuan slope kurva sorpsi isotermis produk kerupuk ikan lele dumbo panggang pada suhu $30^{\circ} \mathrm{C}$ (model Halsey).

Figure 7. Determination of slope of isotherm sorption curve of roasted catfish crackers product at $30^{\circ} \mathrm{C}$ (Halsey model).

Tabel 8. Variabel pendukung dalam penentuan umur simpan kerupuk ikan lele dumbo panggang Table 8. Supporting variable used in shelf-life determination of roasted catfish crackers

\begin{tabular}{|c|c|c|}
\hline \multirow[b]{2}{*}{ Parameter/ Parameters } & \multicolumn{2}{|c|}{ Jenis Plastik Kemasan/Type of packaging } \\
\hline & $\begin{array}{l}\text { Polipropilen/ } \\
\text { Polypropilene (PP) }\end{array}$ & Metalik/Metallic \\
\hline \multicolumn{3}{|l|}{ Permeabilitas uap air kemasan/Permeability of packaging $(\mathrm{k} / \mathrm{x})$} \\
\hline $\begin{array}{l}\text { Nilai Water Vapor Transmission Rate (WVTR) }(\mathrm{g} / \mathrm{m} 2 \text {.hari)/WVTR value } \\
\left(\mathrm{g} / \mathrm{m}^{2} \text {.day) }\right.\end{array}$ & 3.87 & 3.2 \\
\hline Tebal kemasan/Thickness of packaging (mm) & 0.130 & 0.110 \\
\hline $\mathrm{RH}$ pengujian/RH of testing (\%), Suhu/ Temperature $\left({ }^{\circ} \mathrm{C}\right)$ & $90 \%, 38^{\circ} \mathrm{C}$ & $90 \%, 38^{\circ} \mathrm{C}$ \\
\hline Tekanan uap jenuh/Saturated steam pressure $(\mathrm{mmHg})$ & 49.157 & 49.157 \\
\hline $\begin{array}{l}\text { Nilai permeabilitas uap air kemasan }(\mathrm{k} / \mathrm{x})(\mathrm{g} / \mathrm{m} 2 \text {. hari.mmHg }) / \text { Permeability of } \\
\text { packaging value }(\mathrm{k} / \mathrm{x})\left(\mathrm{g} / \mathrm{m}^{2} \text {.day. } \mathrm{mmHg}\right)\end{array}$ & 0.0114 & 0.008 \\
\hline \multicolumn{3}{|l|}{ Luas kemasan/Packaging area (A) } \\
\hline Panjang/Length (m) & 0.26 & 0.26 \\
\hline Lebar/Width (m) & 0.18 & 0.18 \\
\hline Luas/Area $(\mathrm{A})\left(\mathrm{m}^{2}\right)$ & 0.0936 & 0.0936 \\
\hline \multicolumn{3}{|l|}{ Variabel pendukung lain/Other supporting variable } \\
\hline Kadar air aw al/Initial moisture content (Mo) & \multicolumn{2}{|c|}{0.0235} \\
\hline$\%$ padatan $/ \%$ solid (\% solid) & \multicolumn{2}{|c|}{97.80} \\
\hline Berat produk per kemasan/Product weight per pack & \multicolumn{2}{|c|}{50} \\
\hline $\begin{array}{l}\text { Berat kering produk dalam kemasan (Ws) (g padatan)/Product dry weight in } \\
\text { packaging (Ws) (g solid) }\end{array}$ & \multicolumn{2}{|c|}{48.90} \\
\hline
\end{tabular}


pada suhu $30^{\circ} \mathrm{C}$. Permeabilitas kemasan diperoleh dengan membagi nilai WVTR $\left(\mathrm{g} / \mathrm{m}^{2}\right.$.hari) dan tebal $(\mathrm{mm})$ kemasan dengan tekanan uap jenuh pada suhu pengujian $38^{\circ} \mathrm{C}$ yakni sebesar $49,1570 \mathrm{mmHg}$ (dibagi dengan $\mathrm{RH}$ pengujian yakni $90 \%$ ) sehingga diperoleh rerata permeabilitas kemasan sebesar $0,0114 \mathrm{~g} /$ $\mathrm{m}^{2}$.hari.mmHg untuk kemasan plastik PP transparan dan $0,0080 \mathrm{~g} / \mathrm{m}^{2}$.hari. $\mathrm{mmHg}$ untuk kemasan plastik metalik. (Tabel 8). Menurut Astrid, Sri, \& Dian (2013), permeabilitas uap air kemasan adalah kemampuan uap air untuk menembus suatu kemasan pada kondisi suhu dan $\mathrm{RH}$ tertentu, sehingga semakin kecil permeabilitas air kemasan maka daya tembus uap air semakin kecil. Semakin rendah nilai permeabilitas uap air kemasan, semakin rendah laju difusi uap air sehingga dapat mempertahankan kerenyahan dan memperpanjang umur simpan produk.
Plastik yang digunakan memiliki ketebalan 130 $\mu \mathrm{m}$ untuk plastik PP transparan dan $110 \mu \mathrm{m}$ untuk plastik metalik. Daya sobek plastik PP transparan hasil pengujian sebesar 150 gram pada kondisi melintang dan 200 gram pada kondisi membujur. Sedangkan daya sobek plastik metalik hasil pengujian sebesar 216,67 gram pada kondisi melintang dan 100 gram pada kondisi membujur. Hasil pengujian daya sobek tersebut menunjukkan bahwa plastik PP transparan lebih mudah sobek pada bagian horisontal/ melintang sedangkan plastik metalik lebih mudah disobek pada bagian vertikal/membujur.

Polipropilen (PP) merupakan salah satu jenis plastik linear hidrokarbon polimer $\left(\mathrm{C}_{n} \mathrm{H}_{2 n}\right)$ yang memiliki daya regang tinggi, tahan bocor, pembatas (sedang) terhadap uap air, gas dan bau serta tidak terpengaruh oleh perubahan kelembaban (Allahvaisi,

Tabel 9. Penentuan umur simpan kerupuk ikan lele dumbo dalam kemasan plastik PP transparan dan plastik metalik pada $\mathrm{RH} 65 \%$

Table 9. Shelf life determination of roasted catfish crackers stored in transparent polypropylene and metallic plastics at $\mathrm{RH}$ of $65 \%$

\begin{tabular}{|c|c|c|}
\hline Parameter/ Parameters & Simbol/Symbols & $\begin{array}{r}\text { Nilai pada } \mathrm{RH} 65 \% \\
\text { Value at } \mathrm{RH} 65 \%\end{array}$ \\
\hline $\mathrm{KA}$ awal $\left(\mathrm{g} \mathrm{H}_{2} \mathrm{O} / \mathrm{g}\right.$ padatan$) / /$ nitial moisture content $\left(\mathrm{g} \mathrm{H}_{2} \mathrm{O} / \mathrm{g}\right.$ solid) & $\mathrm{Mi}$ & 0.0235 \\
\hline KA kritis ( $\mathrm{g} \mathrm{H}_{2} \mathrm{O} / \mathrm{g}$ padatan)/Critical moisture content $\left(\mathrm{g} \mathrm{H}_{2} \mathrm{O} / \mathrm{g}\right.$ solid) & Mc & 0.0538 \\
\hline Slope kurva sorpsi isotermis/Slope of isotherm sorption curve & $\mathrm{b}$ & 0.5088 \\
\hline $\begin{array}{l}\text { KA kesetimbangan ( } \mathrm{g} \mathrm{H}_{2} \mathrm{O} / \mathrm{g} \text { padatan)/Equilibrum moisture content } \\
\left(\mathrm{g} \mathrm{H}_{2} \mathrm{O} / \mathrm{g} \text { solid) }\right.\end{array}$ & $\mathrm{Me}$ & 0.1353 \\
\hline $\begin{array}{l}\text { Permeabilitas kemasan plastik PP transparan }\left(\mathrm{g} / \mathrm{m}^{2} . \text { hari. } \mathrm{mmHg}\right) / \\
\text { Permeability of transparent PP packaging }\left(\mathrm{g} / \mathrm{m}^{2} . \text { day. } \mathrm{mmHg}\right)\end{array}$ & $k / x$ & 0.0114 \\
\hline $\begin{array}{l}\text { Permeabilitas kemasan plastik metalik }\left(\mathrm{g} / \mathrm{m}^{2} . \text { hari. } \mathrm{mmHg}\right) / \\
\text { Permeability of metallic plastic packaging }\left(\mathrm{g} / \mathrm{m}^{2} . \text { day. } \mathrm{mmHg}\right)\end{array}$ & $k / x$ & 0.0080 \\
\hline Luas kemasan/Packaging area $\left(m^{2}\right)$ & A & 0.0936 \\
\hline Berat padatan per kemasan/Solid weight per pack & Ws & 48.9 \\
\hline Tekanan uap air jenuh/Saturated steam pressure $(\mathrm{mmHg})$ & Po & 31.824 \\
\hline \multicolumn{3}{|l|}{ Umur simpan PP transparan/Shelf life of transparent PP packaging : } \\
\hline - hari/day & & 231 \\
\hline - bulan/month & & 8 \\
\hline \multicolumn{3}{|l|}{ Umur simpan PP metalik/Shelf life of metallic packaging : } \\
\hline - hari/day & & 329 \\
\hline - bulan/month & & 11 \\
\hline
\end{tabular}


2012) sehingga cocok untuk digunakan sebagai pengemas makanan ringan dan produk kering.

Kemasan yang digunakan memiliki luas sebesar $26 \mathrm{~cm} \times 18(\mathrm{~cm}) \times 2$ bidang permukaan yaitu $936 \mathrm{~cm}^{2}$ atau setara dengan 0,0936 $\mathrm{m}^{2}$. Semakin besar luas kemasan yang digunakan dapat memperpanjang umur simpan yakni dengan memperlambat laju uap air. Berat padatan per kemasan dipengaruhi oleh kadar air awal dan berat produk yang akan dikemas. Berat kerupuk ikan lele dumbo panggang sekitar 10 gram/ keping, dan per kemasan plastik berisi 5 keping kerupuk sehingga berat total kerupuk per kemasan ditentukan sebesar \pm 50 gram. Dari perhitungan berat padatan per kemasan diperoleh nilai Ws sebesar 48,90 .

\section{Umur Simpan Kerupuk Ikan Lele Dumbo Panggang}

Penentuan umur simpan pada penelitian ini menggunakan metode akselerasi pendekatan kadar air kritis pada $\mathrm{RH}$ penyimpanan produk sebesar $65 \%$ atau nilai kelembaban udara sehari-hari. Hasil menunjukkan bahwa umur simpan kerupuk ikan lele dumbo yang dikemas dengan plastik metalik adalah 329 hari terhitung lebih panjang dibandingkan umur simpan kerupuk ikan lele dumbo panggang yang dikemas dengan plastik PP transparan yaitu 231 hari (Tabel 9). Hal ini disebabkan oleh permeabilitas uap air plastik metalik $\left(0,0080 \mathrm{~g} / \mathrm{m}^{2}\right.$.hari. $\left.\mathrm{mmHg}\right)$ yang lebih rendah dibandingkan PP transparan $(0,0114 \mathrm{~g} /$ $\mathrm{m}^{2}$.hari.mmHg). Pengemasan bahan pangan harus memperhatikan sifat bahan pangan yang akan dikemas, keadaan lingkungan tempat penyimpanan dan sifat bahan pengemas. Pada produk kerupuk, kadar air berpengaruh besar dalam mutu kerupuk untuk dapat diterima oleh konsumen sehingga harus dipilih kemasan yang memiliki permeabilitas rendah terhadap uap air untuk mencegah kerupuk menjadi hilang kerenyahan. Pengemasan dapat memperpanjang umur simpan dan mempertahankan kualitas bahan lebih lama (Astrid et al., 2013).

\section{KESIMPULAN}

Berdasarkan data hasil penelitian didapatkan nilai kadar air kritis kerupuk ikan lele dumbo panggang $0,538 \mathrm{~g} \mathrm{H}_{2} \mathrm{O} / \mathrm{g}$ padatan (bk) pada waktu pengamatan 76 menit berdasarkan skor kerenyahan, nilai $a_{w}$ sebesar 0,376 tingkat kekerasan 18,920 $\mathrm{N}$ dan daya patah 19,456 N, kadar air kesetimbangan pada $\mathrm{RH}$ $65 \%$ sebesar $0,1353 \mathrm{~g} \mathrm{H}_{2} \mathrm{O} / \mathrm{g}$ padatan (bk), berat padatan per kemasan 48,90 dan slope (b) kurva sorpsi isotermis 0,5080 . Plastik yang digunakan memiliki luas sebesar 0,0936 $\mathrm{m}^{2}$ dan permeabilitas uap air sebesar $0,0114 \mathrm{~g} / \mathrm{m}^{2}$.hari.mmHg untuk plastik PP dan $0,0080 \mathrm{~g} / \mathrm{m}^{2}$.hari.mmHg untuk plastik metalik. Dengan demikian maka diperoleh umur simpan kerupuk ikan lele dumbo panggang dengan kemasan plastik metalik adalah 329 hari, lebih panjang dibandingkan dengan kemasan plastik polipropilen $(P P)$ yaitu 231 hari.

\section{DAFTAR PUSTAKA}

Adawiyah, D. R., \& Soekarto, S. T. (2010). Pemodelan isotermis sorpsi air pada model pangan. Jurnal Tek. dan Industri Pangan, XXI(1), 33-39

Allahvaisi, S. (2012). Polypropylene in the industry of food packaging. In : Polypropylene, Dr. Fatih Dogan (Ed), ISSBN : 978-953-51-0636-4, InTech Open Access Publisher.

Anonim. (2008). Packaging materials for food. Technical Brief, Practical Action.

Anonim. (2017). Overview of texture profile analysis. Diunduh dari http://texturetechnologies.com/ resources/texture-profile-analysis\#examples-ofgraphs

Astrid, W., Sri, W., \& Dian, N. D. (2013). Prediction of self life of Kemplang Crackers Packaged in Polypropilene Plastick with Tickneses. J.Agr. Eng. Lampung 2(2): 105-114.

Badan Standarisasi Nasional (BSN). (2011). SNI 23462011. Petunjuk Pengujian Organoleptik dan atau sensori pada Produk Perikanan. 17 hal.

Budijanto, S., Sitanggang, A. B., \& Kartika, Y. D. (2010). Penentuan umur simpan tortilla dengan metode akselerasi berdasarkan kadar air kritis serta pemodelan ketepatan sorpsi isothermnya. J. Teknol. dan Industri Pangan, XXI(2) : 165-170

Caurie, M. (1981). Derivation of full range moisturesorption isotherms. In: Rockland, L.B.; dan Stewart, G.F. (eds). Water Activity: Influence on Food Quality. Academic Press, New York, NY, USA

Chen, C. S., \& Clayton, J. T. (1971). The effect of temperature on sorption isotherms of biological materials. Trans. Of ASAE., 14(5), 927-929

Faridah, D. N., Yasni, S., Suswantinah, A., \& Aryani, G. W. (2013). Pendugaan umur simpan dengan metode Accelerated Shelf-Life Testing pada produk bandrek instan dan sirup buah pala (Myristica fragrans). Jurnal IImu Pertanian Indonesia (JIPI), 18(3), 144-153.

Guggenheim, E. A.,Anderson, R. B., \& De Boer, J. H. (GAB). (1981). Applications of statistical mechanics. Clarendon Press, Oxford, UK.

Halsey, G. (1948). Physical adsorption on non-uniform surfaces. Journal of Chemistry and Physics, 16, 931937.

Henderson, S. M. (1952). A basic concept of equilibrium moisture content. Agric. Eng., 33 (2): 29-32.

Herawati, H. (2008). Penentuan umur simpan pada produk pangan. Jurnal Litbang Pertanian, 27 (4), 124130 
Histifarina, D. (2015). Pendugaan umur simpan dan model kurva isoterma sorpsi air tepung pisang. Prosiding Balai Pengkajian Teknologi Pertanian Lampung. Badan Penelitian dan Pengembangan Pertanian Kementrian Pertanian. Diunduh dari http:/ /lampung.litbang.pertanian.go.id/ind/index.php/ publikasi/prosiding/582-pendugaan-umur-simpandan-model-kurva-isoterma-sorpsi-air-tepungpisang.

Huda, N., Boni, I., \& Noryati, I.(2009). The effect of different ratios of dory fish to tapioca flour on the linear expansion, oil absorption, colour and hardness of fish crackers. International Food Research Journal, 16: 159-165.

Kaymak-Ertekin, F \& Gedik, A. (2004). Sorption isotherms and isosteric heat of sorption for grapes, apricots, apples and potatoes. Lebensm.-Wiss.u.-Technol., 37 :429-438.

Koswara, S. (2009). Pengolahan Aneka Kerupuk. Ebookpangan.com.

Labuza, T.P. (1982). Shelf Life Dating of Foods. Food dan Nutrition Press., Inc., Westport, Connecticut

McMinn, W. A. M., \& Magee, T. R. A. (1999). Studies on the effect of temperature on the moisture sorption characteristics of potatoes. Journal of Food Process Engineering, 22, 113-128

McMinn, W.A.M \& Magee, T.R.A. (2003). Thermodynamic properties of moisture sorption of potato. Journal of Food Engineering, 60: 155-157

Obande, R. A, Omeji, S., \& Ityumbe, M. (2012). Organoleptic assesment dan nutritive values of Clarias gariepinus smoked using coal dan firewood. Pakistan Journal of Nutrition 11 (9) : 762-764

Oswin, C.R. (1946). The kinetics of package life III: The isotherms. J. Chem. Ind. 65, 419-23

BPOM. (2007). Peraturan KBPOM RI No. HK.00.05.55.6497 tentang Bahan Kemasan Pangan. BPOM RI. Jakarta

Rossa, R, Narcisa M. B., \& Maria L. N. (2007). Nutritional quality of African Catfish Clarias gariepinus (Burchell 1822) : A positive criterion for the future development of the European production of siluroidei). International Journal of Food Science dan Technology $42,342-351$

Sanjaya, Y.(2007). Pengaruh lama perputaran spinner dalam pembuatan keripik salak (Salacca edulis
Reinw.) terhadap pendugaan umur simpan dengan kemasan plastik oriented polipropilene (OPP), metalized (Co-PP/Me) dan alumunium foil. Skripsi. Fakultas Pertanian, Institut Pertanian Bogor. Bogor.

Septianingrum, E. (2008). Perkiraan umur simpan tepung gaplek yang dikemas dalam berbagai kemasan plastik berdasarkan kurva isoterm sorpsi lembab. Skripsi. Fakultas Pertanian. Universitas Sebelas Maret. Surakarta.

Sugiyono, Edi S, Elvira S \& Hery S. (2011). Pengembangan produk mi kering dari tepung ubi jalar (Ipomoea batatas) dan penentuan umur simpannya dengan metode isoterm sorpsi. J. Teknol dan Industri Pangan, XXII(2): 164:170

Suryaningrum, D., Rosmawaty P., ljah M., Diah I., \& Syamdidi. (2014). Peningkatan nilai tambah produk ikan air tawar. Laporan Teknis. Balai Besar Penelitian dan Pengembangan Kelautan dan Perikanan. Jakarta

Suryaningrum, D., Ikasari, D., Supriyadi, Intimulya \& Purnomo, A.H. (2016). Karakteristik kerupuk panggang ikan Lele (Clarias gariepinus) dari beberapa perbandingan daging ikan dan tepung tapioka. Jurnal Pascapanen dan Bioteknologi Kelautan dan Perikanan 11(1): 25-40.

Syarif, R \& Halid, H. (1993). Teknologi penyimpanan pangan. PAU Rekayasa Proses Pangan, IPB, Bogor.

Tarigan, E., Prateepchaikul, G., Yamsaengsung, R., Sirichote, A. \& Tekasakul, P. (2006). Sorption isotherms of shelled and unshelled kernels of candle nuts. Journal of Food Engineering.;75:447-452.

Trinoviyani, (2015). Studi pendugaan umur simpan cabai bubuk fermentasi dari cabai merah dan cabai rawit menggunakan metode akselerasi pendekatan Labuza. Skripsi. Ilmu dan Teknologi Pangan, Universitas Hasanudin, Makasar.

UUD RI. (1996). Pangan. Undang-Undang Republik Indonesia No.7 tahun 1996. Jakarta.

UUD RI. (1999) . Perlindungan Konsumen. UndangUndang Republik Indonesia No.8 tahun 1999. Jakara

UUD RI. (2012). Pangan. Undang-Undang Republik Indonesia No 18 tahun 2012. Jakarta.

Vazquez, G.,Chenlo, F.\& Moreira, R.(2003). Sorption isotherms of lupine at diûerent temperatures. Journal of Food Engineering, 60,449-452. 
JPB Kelautan dan Perikanan Vol. 12 No. 1 Tahun 2017: 55-70 